\section{Factors associated with smoking cessation in Brazil}

\author{
Fatores associados à cessação do tabagismo \\ no Brasil
}

\author{
Factores asociados con el abandono del \\ tabaquismo en Brasil
}

Cesar Augusto Oviedo Tejada 1

Fernanda Ewerling 2

Anderson Moreira Aristides dos Santos 3

Andréa Dâmaso Bertoldi 2

Ana Maria Menezes 2

\section{Resumo}

Tobacco has been identified as the drug with the highest addiction rate and the leading cause of avoidable deaths. The current study thus aimed to identify the determinants of smoking cessation in a Brazilian population sample based on data from the National Household Sample Survey for 2008. The study analyzed socioeconomic, residential, and health-related data as well as individual habits. Data analysis used Poisson regression. The following factors were associated with smoking cessation: age 45 years or older, higher income, medical consultation in the previous 12 months, private health plan, physical exercise, believing that smoking is bad for one's health and that cigarette smoke is harmful to passive smokers, and Internet access in the household. Subjects with heart conditions, diabetes, and cancer were also more prone to quit smoking.

Tobacco Use Cessation; Tobacco; Socioeconomic Factors;
O tabaco é apontado como a droga com maior porcentual de dependência entre as drogas aditivas e, também, como o maior causador de mortes evitáveis. Nesse sentido, este estudo visou a encontrar os determinantes de cessação do tabagismo para a população brasileira com base nos dados da Pesquisa Nacional por Amostra de Domicílios de 2008. Foram analisadas informações socioeconômicas, de zona e região de residência, de saúde e hábitos dos indivíduos. A análise dos dados envolveu estimações utilizando-se a regressão de Poisson. Os resultados mostram que fatores como ter 45 anos ou mais, possuir renda mais elevada, ter consultado médico nos últimos 12 meses, ter plano de saúde, praticar exercícios físicos, acreditar que o tabaco faz mal à saúde, que a fumaça do cigarro compromete a saúde dos fumantes passivos, e ter Internet no domicílio se relacionam positivamente com a cessação do tabagismo. Além disso, pessoas com problemas cardíacos, diabetes e câncer mostraram uma maior propensão a deixar de fumar.

Abandono do Uso de Tabaco; Tabaco; Fatores Socioeconômicos 


\section{Introduction}

Tobacco use, formerly considered a "lifestyle", is now recognized for the harm it causes to health due to the exposure to numerous toxic substances 1 . With nicotine as the main psychoactive component of tobacco, smoking shows the highest addiction rate among legal and illicit drugs 2 and is further identified as the leading cause of avoidable mortality, causing some 6 million deaths every year and huge damage to the world economy. If the current trend continues, by 2030 smoking will cause an estimated 8 million deaths per year in the world 3 .

In Brazil in 2008, there were some 24.6 million smokers in the adult population, or $17.2 \%$ of this age bracket. Prevalence of tobacco use was $21.6 \%$ in men and $13.1 \%$ in women ${ }^{4}$. As for the desire to stop smoking, $45.6 \%$ of Brazilian smokers had made some attempt to quit in the previous 12 months 4 . Among those that try, it is known that few succeed because of various factors, including work stress ${ }^{5}$. Evidence also shows that smoking cessation is associated with: more schooling $6,7,8,9$, older age $6,7,8$, medical consultation at least once a year 6,7, marital status (married) 6,8, male gender 8,10,11,12, and white skin color 8 . Research has also shown that price increases for cigarettes increase the quit rates 13 . According to estimates, a permanent increase of $10 \%$ in future cigarette prices would reduce the mean duration of smoking by $11 \%-13 \% 14$

Various studies have attempted to identify psychological 2,15,16 and/or work and household-related factors 5 that lead individuals to quit smoking, but there are few analyses of the socioeconomic factors associated with this outcome, especially in the Brazilian population 6 . Other studies have sought evidence of an association between smoking and certain diseases 2 , but few have attempted to determine whether these diseases are relevant motivating factors to quit smoking. In order to fill this knowledge gap, the current study aimed to identify the socioeconomic, health-related, and residential determinants associated with smoking cessation in the Brazilian population.

\section{Methods}

Data were obtained from the Brazilian National Household Sample Survey (PNAD), 2008. The PNAD is a nationwide survey conducted by the Brazilian Institute of Geography and Statistics (IBGE). The survey publishes periodic supplements on specific themes, including smoking in 2008.
For this supplement of PNAD 2008, the IBGE and Ministry of Health joined to conduct the Special Survey on Smoking (PETab), using the international methodology from the Global Adult Tobacco Survey (GATS); the latter has evaluated smoking in various developing countries to support the international Tobacco Free Initiative 17 . PETab studied individuals 15 years or older on consumption of tobacco and tobacco products, attempts at cessation, indirect exposure to cigarette smoke, access to awareness-raising campaigns concerning the risks associated with smoking, and perception of these risks 18 .

In 2008, the Brazilian survey included 391,868 individuals and 150,591 households in all States of the country and the Federal District.

The following inclusion criterion was used, adopting definitions from the World Health Organization (WHO) 19: self-reported current smoker or former daily smoker. WHO defines smokers as individuals that smoke at least one cigarette per day and former smokers as those who previously smoked at least one cigarette a day but quit smoking at least six months before. Thus, for the analyses in the current article, the sample resulted in 11,933 smokers and former daily smokers 15 years or older.

The following independent variables were used to analyze determinants of smoking cessation: per capita household income (in quartiles, with lowest income as the $1^{\text {st }}$ quartile), schooling in years (grouped in five categories: zero, 1-3, 4-7, 8-10, and $\geq 11$ years), age (15-29, 30-59, and $\geq 60$ years), age at smoking onset ( $<18$ years and $\geq 18$ years), gender, and self-rated health (very good or good versus fair, poor, or very poor).

The study also used three indicators on healthcare and two on knowledge of harm from smoking: medical consultation in the last 12 months (yes/no), private health plan (yes/no), and physical exercise or sports at least one or two days a week in the previous three months (yes/no); believing that smoking causes serious diseases (yes/no) and believing that cigarette smoke causes serious diseases in passive smokers (yes/no).

The study also analyzed self-report of the following diseases based on a medical diagnosis: heart disease, hypertension, depression, diabetes, bronchitis, or cancer; possessing the following items (markers for access to information) in the household: TV, internet, or radio; region of the country (North, Northeast, South, Southeast, and Central-West); and area of residence (urban versus rural).

Smoking cessation prevalence rates were also calculated with their respective $95 \%$ confidence intervals, as were crude and adjusted prevalence 
ratios, using Poisson regression. Multivariate analysis included all the independent variables and indicators for healthcare and knowledge on harm from smoking.

All the analyses used Stata 11.0 (Stata Corp., College Station, USA). Considering that the PNAD is a complex sample, svyset command was used to define the sample weights and clusters and svy for the analyses to contemplate this sampling design.

\section{Results}

Prevalence of smoking cessation among the 11,393 individuals included in the analysis was 48.18\% (95\%CI: 47.02; 49.32). Table 1 shows the percentage of subjects that quit smoking according to demographics, socioeconomic status, place of residence, self-rated health, and sources of information in the household.

Some $49.1 \%$ of women in the sample had quit smoking more than 6 months previously, as compared to $47.6 \%$ in men (difference not statistically significant). Individuals 60 years or older showed a much higher cessation rate $(69.6 \%)$, nearly three times that of younger individuals (24.6\%). Cessation rates also increased in direct proportion to income.

Table 2 shows the crude and adjusted prevalence ratios for factors associated with smoking cessation and respective confidence intervals, obtained by Poisson regression. The results of the crude analysis were quite similar to those found in the preliminary analysis shown in Table 1. Gender continued not to show statistical significance, and older individuals continued to present a higher propensity to quit smoking.

Individuals with 4-10 years of schooling showed lower smoking cessation rates than those with no schooling. However, income still showed a positive relationship with the outcome.

As for place of residence, urban dwellers were more prone to quit smoking than rural residents. There was no significant difference according to geographic region of the country.

Individuals that rated their health as very good or good showed lower cessation rates than those who rated their health as fair, poor, or very poor. Individuals with heart disease, diabetes, hyper-

\section{Table 1}

Prevalence of smoking cessation according to individual characteristics in the Brazilian population 15 years or older. Brazilian National Household Sample Survey (PNAD), Brazil, 2008-2009 ( $N=11,393)$.

\begin{tabular}{|c|c|c|c|c|}
\hline \multirow[t]{2}{*}{ Variables } & \multirow[t]{2}{*}{ Sample } & \multicolumn{2}{|c|}{ Quit smoking } & \multirow[t]{2}{*}{$p$-value $\left(\chi^{2}\right)$} \\
\hline & & n & $\%(95 \% \mathrm{Cl})$ & \\
\hline \multicolumn{5}{|c|}{ Demographic and socioeconomic } \\
\hline \multicolumn{5}{|l|}{ Gender } \\
\hline Male & 6,524 & 3,101 & $47.55(45.99 ; 49.12)$ & 0.196 \\
\hline Female & 4,869 & 2,393 & $49.11(47.36 ; 50.87)$ & \\
\hline \multicolumn{5}{|l|}{ Age (years) } \\
\hline $15-29$ & 1,703 & 457 & $24.65(22.33 ; 27.13)$ & $<0.001$ \\
\hline $30-59$ & 6,980 & 3,182 & $46.20(44.72 ; 47.68)$ & \\
\hline$\geq 60$ & 2,710 & 1,855 & $69.61(67.48 ; 71.66)$ & \\
\hline Schooling (years) & & & & 0.001 \\
\hline 0 & 2,165 & 1,103 & $52.48(49.86 ; 55.08)$ & \\
\hline $1-3$ & 1,697 & 833 & $48.75(45.84 ; 51.67)$ & \\
\hline $4-7$ & 3,176 & 1,453 & $45.51(43.43 ; 47.60)$ & \\
\hline $8-10$ & 1,675 & 749 & $45.71(42.75 ; 48.69)$ & \\
\hline$\geq 11$ & 2,680 & 1,356 & $49.24(46.78 ; 51.70)$ & \\
\hline Income (quartiles) & & & & $<0.001$ \\
\hline 1 st & 3,042 & 1,230 & $40.27(38.11 ; 42.47)$ & \\
\hline $2^{\text {nd }}$ & 2,669 & 1,223 & $47.08(44.89 ; 49.28)$ & \\
\hline $3 r d$ & 2,845 & 1,461 & $50.51(48.21 ; 52.81)$ & \\
\hline 4 th & 2,837 & 1,580 & $55.60(53.20 ; 57.98)$ & \\
\hline
\end{tabular}

(continues) 


\begin{tabular}{|c|c|c|c|c|}
\hline \multirow[t]{2}{*}{ Variables } & \multirow[t]{2}{*}{ Sample } & \multicolumn{2}{|c|}{ Quit smoking } & \multirow[t]{2}{*}{$p$-value $\left(\chi^{2}\right)$} \\
\hline & & $\mathrm{n}$ & $\%(95 \% \mathrm{Cl})$ & \\
\hline \multicolumn{5}{|l|}{ Residence } \\
\hline Area of residence & & & & 0.019 \\
\hline Rural & 1,963 & 867 & $45.25(42.56 ; 47.96)$ & \\
\hline Urban & 9,430 & 4,627 & $48.80(47.52 ; 50.08)$ & \\
\hline Region of residence & & & & 0.392 \\
\hline North & 1,207 & 591 & $47.41(43.35 ; 51.52)$ & \\
\hline Northeast & 3,343 & 1,640 & $49.27(47.20 ; 51.34)$ & \\
\hline South & 2,055 & 947 & $46.58(43.88 ; 49.30)$ & \\
\hline Southeast & 3,453 & 1,651 & $47.90(45.96 ; 49.85)$ & \\
\hline Central-West & 1,335 & 665 & $50.17(46.93 ; 53 ; 40)$ & \\
\hline \multicolumn{5}{|l|}{ Health-related variables } \\
\hline Self-rated health & & & & $<0.001$ \\
\hline Fair, poor, or very poor & 4,359 & 2,366 & $54.09(52.28 ; 55.89)$ & \\
\hline Very good or good & 7,034 & 3,128 & $44.54(43.06 ; 46.04)$ & \\
\hline Heart disease & & & & $<0.001$ \\
\hline No & 10,525 & 4,910 & $46.64(45.41 ; 47.87)$ & \\
\hline Yes & 868 & 584 & $66.90(62.85 ; 70.72)$ & \\
\hline \multicolumn{5}{|l|}{ Depression } \\
\hline No & 10,521 & 5,071 & $48.26(47.05 ; 49.48)$ & $<0.618$ \\
\hline Yes & 872 & 423 & $47.20(43.21 ; 51.22)$ & \\
\hline \multicolumn{5}{|l|}{ Diabetes } \\
\hline No & 10,636 & 4,960 & $46.71(45.51 ; 47.92)$ & $<0.001$ \\
\hline Yes & 757 & 534 & $69.12(64.71 ; 73.21)$ & $<0.001$ \\
\hline \multicolumn{5}{|l|}{ Hypertension } \\
\hline No & 8,471 & 3,625 & $42.76(41.41 ; 44.12)$ & \\
\hline Yes & 2,992 & 1,869 & $63.80(61.56 ; 65.97)$ & \\
\hline Bronchitis & & & & 0.191 \\
\hline No & 10,835 & 5,213 & $48.01(46.81 ; 49.21)$ & \\
\hline Yes & 558 & 281 & $51.51(46.41 ; 56.59)$ & $<0.001$ \\
\hline \multicolumn{5}{|l|}{ Cancer } \\
\hline No & 11,259 & 5,398 & $47.89(46.71 ; 49.07)$ & \\
\hline Yes & 134 & 96 & $73.05(63.10 ; 81.12)$ & \\
\hline Physician consultation in previous year & & & & $<0.001$ \\
\hline No & 3,442 & 1,304 & $38.44(36.31 ; 40.60)$ & \\
\hline Yes & 7,951 & 4,190 & $52.53(51.20 ; 53.87)$ & \\
\hline Private health plan & & & & $<0.001$ \\
\hline No & 8,939 & 4,105 & $45.90(44.58 ; 47.22)$ & \\
\hline Yes & 2,454 & 1,389 & $55.91(53.39 ; 58.40)$ & \\
\hline Physical exercise or sports & & & & $<0.001$ \\
\hline No & 9,005 & 4,666 & $46.57(45.28 ; 47.86)$ & \\
\hline Yes & 2,388 & 828 & $54.26(51.76 ; 56.74)$ & \\
\hline Believes smoking causes diseases & & & & $<0.001$ \\
\hline No & 10,786 & 192 & $30.26(26.05 ; 34.83)$ & \\
\hline Yes & 607 & 5,302 & $49.22(48.01 ; 50.44)$ & \\
\hline Believes cigarette smoke causes diseases & & & & $<0.001$ \\
\hline \multicolumn{5}{|l|}{ in passive smokers } \\
\hline No & 1,298 & 475 & $35.14(32.05 ; 38.36)$ & \\
\hline Yes & 10,095 & 5,019 & $49.86(48.62 ; 51.09)$ & \\
\hline Age at smoking onset (years) & & & & 0.813 \\
\hline$<18$ & 7,283 & 3,534 & $48.09(46.67 ; 49.51)$ & \\
\hline$\geq 18$ & 4,110 & 1,960 & $48.37(46.45 ; 50.28)$ & \\
\hline
\end{tabular}

(continues) 


\begin{tabular}{|c|c|c|c|c|}
\hline \multirow[t]{2}{*}{ Variables } & \multirow[t]{2}{*}{ Sample } & \multicolumn{2}{|c|}{ Quit smoking } & \multirow[t]{2}{*}{$p$-value $\left(\chi^{2}\right.$} \\
\hline & & $\mathrm{n}$ & $\%(95 \% \mathrm{Cl})$ & \\
\hline \multicolumn{5}{|l|}{ Access to information } \\
\hline TV in the household & & & & 0.014 \\
\hline No & 823 & 356 & $42.99(38.87 ; 47.22)$ & \\
\hline Yes & 10,570 & 5,138 & $48.49(47.28 ; 49.69)$ & \\
\hline Radio in the household & & & & 0.001 \\
\hline No & 1,506 & 658 & $42.50(39.30 ; 45.77)$ & \\
\hline Yes & 9,887 & 4,836 & $48.85(47.61 ; 50.09)$ & $<0.001$ \\
\hline \multicolumn{5}{|l|}{ Internet in the household } \\
\hline No & 9,439 & 4,422 & $46.51(45.28 ; 47.75)$ & \\
\hline Yes & 1,954 & 1,072 & $54.42(51.64 ; 57.18)$ & \\
\hline
\end{tabular}

95\% Cl: 95\% confidence interval.

Table 2

Crude and adjusted * prevalence ratios (PR) for factors associated with smoking cessation in the Brazilian population 15 years or older. Brazilian National Household Sample Survey (PNAD), Brazil, 2008-2009 (N =11,393).

\begin{tabular}{|c|c|c|}
\hline Variables & Crude PR $(95 \% \mathrm{Cl})$ & Adjusted PR (95\%Cl) \\
\hline \multicolumn{3}{|c|}{ Demographic and socioeconomic } \\
\hline Gender & $p=0.196$ & $p=0.469$ \\
\hline Male & 1.00 & 1.00 \\
\hline Female & $1.03(0.98 ; 1.08)$ & $1.02(0.97 ; 1.07)$ \\
\hline Age (years) & $p<0.001$ & $p<0.001$ \\
\hline $15-29$ & 1.00 & 1.00 \\
\hline $30-59$ & $1.87(1.69 ; 2.07)$ & $1.80(1.63 ; 1.99)$ \\
\hline$\geq 60$ & $2.82(2.55 ; 3.12)$ & $2.60(2.33 ; 2.90)$ \\
\hline Schooling (years) & $p<0.001$ & $p=0.450$ \\
\hline 0 & 1.00 & 1.00 \\
\hline $1-3$ & $0.93(0.86 ; 1.01)$ & $1.00(0.93 ; 1.08)$ \\
\hline $4-7$ & $0.87(0.81 ; 0.93)$ & $0.99(0.92 ; 1.06)$ \\
\hline $8-10$ & $0.87(0.80 ; 0.94)$ & $1.03(0.95 ; 1.12)$ \\
\hline$\geq 11$ & $0.94(0.88 ; 1.01)$ & $0.95(0.94 ; 1.12)$ \\
\hline Income (quartiles) & $p<0.001$ & $p=0.0142$ \\
\hline 1 st & 1.00 & 1.00 \\
\hline $2^{\text {nd }}$ & $1.17(1.09 ; 1.26)$ & $1.10(1.03 ; 1.18)$ \\
\hline $3 r d$ & $1.25(1.17 ; 1.34)$ & $1.07(1.01 ; 1.14)$ \\
\hline $4^{\text {th }}$ & $1.38(1.29 ; 1.48)$ & $1.13(1.04 ; 1.22)$ \\
\hline \multicolumn{3}{|l|}{ Residence } \\
\hline Area of residence & $p=0.022$ & $p=0.839$ \\
\hline Rural & 1.00 & 1.00 \\
\hline Urban & $1.08(1.01 ; 1.15)$ & $1.01(0.94 ; 1.08)$ \\
\hline Region of residence & $p=0.392$ & $p=0.001$ \\
\hline North & 1.00 & 1.00 \\
\hline Northeast & $1.04(0.94 ; 1.14)$ & $0.98(0.89 ; 1.07)$ \\
\hline South & $0.98(0.89 ; 1.09)$ & $0.88(0.79 ; 0.97)$ \\
\hline Southeast & $1.01(0.92 ; 1.11)$ & $0.87(0.80 ; 0.95)$ \\
\hline Central-West & $1.06(0.95 ; 1.18)$ & $0.97(0.88 ; 1.07)$ \\
\hline
\end{tabular}

(continues) 


\begin{tabular}{|c|c|c|}
\hline Variables & Crude PR $(95 \% \mathrm{Cl})$ & Adjusted PR $(95 \% \mathrm{Cl})$ \\
\hline \multicolumn{3}{|l|}{ Health-related variables } \\
\hline Self-rated health & $p<0.001$ & $p=0.442$ \\
\hline Fair, poor, or very poor & 1.00 & 1.00 \\
\hline Very good or good & $0.82(0.79 ; 0.86)$ & $0.98(0.93 ; 1.03)$ \\
\hline Heart disease & $p<0.001$ & $p=0.012$ \\
\hline No & 1.00 & 1.00 \\
\hline Yes & $1.44(1.34 ; 1.53)$ & $1.09(1.02 ; 1.17)$ \\
\hline Depression & $p=0.621$ & $p=0.002$ \\
\hline No & 1.00 & 1.00 \\
\hline Yes & $0.98(0.90 ; 1.07)$ & $0.87(0.80 ; 0.95)$ \\
\hline Diabetes & $p<0.001$ & $p=0.001$ \\
\hline No & 1.00 & 1.00 \\
\hline Yes & $1.48(1.39 ; 1.58)$ & $1.12(1.05 ; 1.19)$ \\
\hline Hypertension & $p<0.001$ & $p<0.001$ \\
\hline No & 1.00 & 1.00 \\
\hline Yes & $1.49(1.42 ; 1.56)$ & $1.17(1.11 ; 1.24)$ \\
\hline Bronchitis & $p=0.177$ & $p=0.674$ \\
\hline No & 1.00 & 1.00 \\
\hline Yes & $1.07(0.97 ; 1.19)$ & $0.98(0.89 ; 1.08)$ \\
\hline Cancer & $p<0.001$ & $p=0.047$ \\
\hline No & 1.00 & 1.00 \\
\hline Yes & $1.53(1.34 ; 1.73)$ & $1.13(1.01 ; 1.28)$ \\
\hline Physician consultation in previous year & $p<0.001$ & $p<0.001$ \\
\hline No & 1.00 & 1.00 \\
\hline Yes & $1.37(1.29 ; 1.45)$ & $1.18(1.11 ; 1.25)$ \\
\hline Private health plan & $p<0.001$ & $p=0.036$ \\
\hline No & 1.00 & 1.00 \\
\hline Yes & $1.22(1.16 ; 1.29)$ & $1.06(1.01 ; 1.13)$ \\
\hline Physical exercise or sports & $p<0.001$ & $p<0.001$ \\
\hline No & 1.00 & 1.00 \\
\hline Yes & $1.17(1.11 ; 1.23)$ & $1.18(1.12 ; 1.24)$ \\
\hline Believes smoking causes diseases & $p<0.001$ & $p<0.001$ \\
\hline No & 1.00 & 1.00 \\
\hline Yes & $1.63(1.40 ; 1.89)$ & $1.40(1.19 ; 1.64)$ \\
\hline Believes cigarette smoke causes diseases in passive smokers & $p<0.001$ & $p<0.001$ \\
\hline No & 1.00 & 1.00 \\
\hline Yes & $1.42(1.29 ; 1.56)$ & $1.28(1.16 ; 1.41)$ \\
\hline Age at smoking onset (years) & $p=0.813$ & $p=0.001$ \\
\hline$<18$ & 1.00 & 1.00 \\
\hline$\geq 18$ & $1.01(0.96 ; 1.06)$ & $0.93(0.88 ; 0.97)$ \\
\hline \multicolumn{3}{|l|}{ Access to information } \\
\hline TV in household & $p=0.019$ & $p=0.494$ \\
\hline No & 1.00 & 1.00 \\
\hline Yes & $1.13(1.02 ; 1.25)$ & $1.04(0.94 ; 1.15)$ \\
\hline Radio in household & $p=0.001$ & $p=0.182$ \\
\hline No & 1.00 & 1.00 \\
\hline Yes & $1.15(1.06 ; 1.25)$ & $1.05(0.98 ; 1.13)$ \\
\hline Internet in household & $p<0.001$ & $p=0.002$ \\
\hline No & 1.00 & 1.00 \\
\hline Yes & $1.17(1.11 ; 1.24)$ & $1.10(1.04 ; 1.17)$ \\
\hline
\end{tabular}

* All the variables included in the model were adjusted for each other. 
tension, and cancer also showed higher quit rates than those not reporting these diseases. Those who had consulted a physician in the previous 12 months, had a health plan, and practiced physical exercise also showed a higher proportion of former smokers.

As for knowledge of harm from smoking, subjects that did not believe that cigarettes cause diseases or that cigarette smoke causes diseases in passive smokers showed lower cessation rates. Individuals with TV, radio, or internet in the household showed higher quit rates than those without.

As for the results of the multivariate analysis, there were few changes in the adjusted prevalence ratios as compared to the crude rates, but some factors were no longer statistically significant, e.g., the schooling variable, where the group with 4 to 10 years no longer showed a statistically significant difference as compared to the group with no schooling. The association with the outcome also disappeared for area of residence, selfrated health, and presence of TV and radio in the household.

Meanwhile, after adjusted analysis, the following variables showed a statistically significant association with lower smoking cessation prevalence ratios: the South and Southeast regions of the country compared to the North; individuals with self-reported depression as compared to without; and individuals that had begun smoking at 18 years or older as compared to those who had started smoking younger.

\section{Discussion}

Smoking cessation has been assessed in relation to various factors, but some factors explored in this study have received little attention in the literature. In addition, no other article was found with such an analysis using nationwide Brazilian data. Our results indicate that factors such as older age, higher income, living in the South and Southeast regions of the country, heart disease, hypertension, diabetes, and cancer and absence of self-reported depression, medical consultation in the previous 12 months, having a health plan, physical exercise at least one or two days a week in the previous three months, believing that smoking is harmful to health and that cigarette smoke causes health problems in passive smokers, and internet access in the household are positively related to smoking cessation.

Data from the PNAD 2008 survey allowed evaluating smoking cessation in a nationally representative sample, but despite the advantage of its scope, its design imposes a limitation that should be considered when assessing the results. The fact that this was a cross-sectional study, where exposure and outcome were collected at the same moment for each individual, could lead to a reverse causality bias, i.e., for individuals that are already ill, those with worse self-rated health, or those with self-reported heart disease, diabetes, or cancer, we have no way of knowing whether the persons became ill and then quit smoking, or vice versa. Therefore, conclusions on higher smoking cessation rates in these groups should consider the possibility that such a bias can distort the interpretations.

Gender did not prove to be a determinant factor for smoking cessation in our study, thus contradicting the findings in other countries, showing significant differences between the sexes $8,10,11,12$, describing women as less prone to quit smoking. In Brazil there is evidence in the literature that this difference does not exist 6 , which corroborates our findings.

As for age, other studies have also shown that older individuals are more likely to quit smoking 6,8,20,21, arguing that with advancing age these individuals gain a greater perception of the harm from cigarettes, besides a greater concern for disease prevention.

Schooling was not associated with smoking cessation in this study. This finding disagrees with the literature, which has shown that individuals with more schooling present higher cessation rates when compared to those with less education 6,7,8,9,21,22. However, such studies do not analyze income and schooling together, and smoking cessation may be more related to income than to schooling, as our results show after adjustment. In addition, some Brazilian studies have not found an association between schooling and smoking among the elderly 23,24.

Meanwhile, income was a significant factor for the outcome (the higher the income, the higher the cessation rate). Other studies have shown similar results 25,26 . A study on the profile of smokers attending the Program for Tobacco Cessation at the Outpatient Clinic on Smoking at the University Hospital in Botucatu, São Paulo State University (UNESP) found that financial status had a large impact on the choice of therapy for smoking cessation (medication, nicotine replacement therapy, or therapy sessions); the high cost of some therapeutic resources makes their use more difficult and in some cases impossible, especially when the individual's income is jeopardized by the chosen treatment 27 .

After adjusted analysis, the South and Southeast regions showed lower cessation rates than the North. An analysis of smoking trends in the Brazilian population 28 based on data from the 
VIGITEL system (Telephone-Based Surveillance of Risk and Protective Factors for Chronic Diseases) ${ }^{29}$ provided results that corroborate our study, with the South and Southeast of Brazil showing lower women's smoking cessation rates as compared to the North. Among men, only the South showed statistically significant results, and in the same direction.

Despite a possible reverse causality bias in this study, other studies corroborate our findings in relation to individuals with heart disease, hypertension, diabetes, or cancer showing higher smoking cessation rates. The fact that less healthy individuals show higher quit rates 30 can be explained by the fact that they are more aware of the harm from cigarettes and also receive closer medical follow-up, and thus receive more cessation counseling aimed at improving their health status. In addition, persons with cancer or heart disease that continue to smoke are subject to greater risk of death $31,32,33$. The literature also indicates that cancer patients are more motivated and interested in quitting smoking 34 .

Having consulted a physician in the previous 12 months was also a significant factor for smoking cessation. The basic approach, namely brief counseling (3-5 minutes) with follow-up to prevent relapses and encouragement for behavioral change in patients that smoke is the duty of all physicians 2; therefore, persons that consult a physician are more likely to have been asked about their interest in quitting. Evidence shows that medical counseling significantly increases the smoking cessation rate as compared to no intervention 35 . In addition, individuals with health plans receive counseling on alcohol consumption and smoking more often than those not covered by such plans 36 , which is consistent with our findings; after all, as mentioned previously, counseling increases the smoking quit rate 35 , so health insurance policy-holders would tend to show higher smoking cessation rates.

Our results show greater propensity to smoking cessation among individuals that practice physical exercise. Similar results were found for sedentary women smokers that were introduced into an aerobic training program combined with a cognitive-behavioral program 37 , where this evidence points to an increase in cessation rates and maintenance of tobacco abstinence among those that participate in the physical exercise program. Other articles in the literature 38,39 also corroborate our findings.

According to the results, individuals that believed that cigarettes are harmful to one's own health or to that of passive smokers are more prone to quit smoking. Periods in which persons are experiencing health problems are favorable to interventions, since certain beliefs, such as the perception of vulnerability, can serve as motivation to adopt a healthier lifestyle; perception of the problem's severity is a determinant factor in openness to the therapeutic process and change 40 . In addition, some regular smokers fail to perceive the risks associated with smoking. Even knowing that some diseases are associated with tobacco use, these individuals do not believe they will become sick. This characteristic is common among persons that have attempted to quit smoking, but without success 40 .

Persons that started smoking $\geq 18$ years of age and those diagnosed with depression experience greater difficulty in quitting. With depression, this may be due to the psychological dependency on tobacco, where smoking serves to relieve internal tension such as feelings of emptiness, anxiety, fear, and stress ${ }^{2}$. Various studies have shown this same exposure as significant in the decision to quit smoking 15,16 . As for age at smoking initiation, studies identify this factor as related to smoking cessation 9,21; however, these studies generally state that individuals who start smoking earlier have more difficulty quitting, which goes against the current study's findings.

Considering information sources, internet access in the home was positively associated with smoking cessation. Ease in access to information and the availability of various websites displaying educational materials on smoking and its harm can facilitate an increase in the population's knowledge and thus in the control of the tobacco epidemic ${ }^{41}$. Thus, persons with online access can increase their awareness of the need to stop smoking in order to avoid jeopardizing their health.

Tobacco is known to cause various diseases, often leading to death. To change the current situation in which more than $17 \%$ of the Brazilian population smokes 4 , in addition to policies that have already been implemented for some time, other more specific plans should be designed in order for more vulnerable groups to obtain greater chances of success in their attempts to quit the habit. It is hoped that smokers will become more aware of the potential harm to their health, and that they will quit smoking before their health problems develop into chronic diseases.

This study's results provide an important contribution to the literature on smoking in Brazil, where studies on smoking cessation are still scarce 6 . Most of the existing articles deal with smoking initiation and the factors and harm associated with tobacco use $2,23,24,28$. In addition, as mentioned above, no similar Brazilian study was found with a nationwide scope. 


\section{Resumen}

El tabaco es considerado como la droga con el porcentaje más alto de dependencia entre las drogas adictivas y principal causa de muertes evitables. Por consiguiente, este estudio tuvo como objetivo encontrar los determinantes en el abandono del tabaco por parte de la población brasileña, usando datos de la PNAD de 2008. Se analizó información socioeconómica, zona y región de residencia, salud y hábitos de la población. El análisis de los datos se realizó mediante la regresión de Poisson. Los resultados muestran que factores tales como: edad avanzada, mayores ingresos, consulta a un médico en los últimos 12 meses, plan privado de salud, hacer ejercicio, creencia en que el tabaco es malo para la salud, $y$ tener Internet en casa, se relacionan positivamente con el abandono del hábito de fumar. Por otra parte, las personas con problemas del corazón, hipertensión, diabetes y cáncer mostraron una mayor propensión a dejar de fumar. Por lo tanto, deben diseñarse planes más específicos de manera que los grupos con mayor vulnerabilidad tengan mejores posibilidades de éxito en el intento para abandonar la adicción.

Cese del Uso de Tabaco; Tabaco; Factores

Socioeconómicos

\section{Contributors}

C. A. O. Tejada, F. Ewerling, and A. M. A. Santos participated in the project design, writing of the article, critical review of the relevant literature and revision of the intellectual content, data analysis and interpretation, and approval of the final version for publication. A. D. Bertoldi and A. M. Menezes participated in the writing of the article, data analysis and interpretation, and approval of the final version for publication.

\section{Acknowledgments}

Fernanda Ewerling wishes to thank CNPq for the scientific initiation grant (121972/2012-7).

\section{References}

1. Instituto Nacional de Câncer. Prevalência de tabagismo no Brasil: dados dos inquéritos epidemiológicos em capitais brasileiras. Rio de Janeiro: Coordenação de Prevenção e Vigilância, Instituto Nacional de Câncer; 2004.

2. Araújo AJ, Menezes AMB, Dórea AJPS, Torres BS, Viegas CAA, Silva CAR, et al. Diretrizes para cessação do tabagismo. J Bras Pneumol 2004; 30 Suppl 2:S1-76.

3. World Health Organization. WHO report on the global tobacco epidemic, 2011: warning about the dangers of tobacco. Geneva: World Health Organization; 2011.

4. Facina T. Pesquisa especial de tabagismo (PETab) relatório Brasil. Rev Bras Cancerol 2011; 57:429-30.
5. Ayyagari P, Sindelar JL. The impact of job stress on smoking and quitting: evidence from the HRS. B E J Econom Anal Policy 2010; 10:article 27.

6. Peixoto SV, Firmo JOA, Lima-Costa MF. Fatores associados ao índice de cessação do hábito de fumar em duas diferentes populações adultas (Projetos Bambuí e Belo Horizonte). Cad Saúde Pública 2007; 23:1319-28.

7. García M, Schiaffino A, Twose J, Borrell C, Saltó E Peris $\mathrm{M}$, et al. Abandono del consumo de tabaco en una cohorte de base poblacional. Arch Bronconeumol 2004; 40:248-354.

8. Kabat GC, Wynder EL. Determinants of quitting smoking. Am J Public Health 1987; 77:1301-5. 
9. Breslau N, Peterson EL. Smoking cessation in young adults: age at initiation of cigarette smoking and other suspected influences. Am J Public Health 1996; 86:214-20.

10. Mackay J, Amos A. Women and tobacco. Respirology 2003; 8:123-30.

11. Wetter DW, Kenford SL, Smith SS, Fiore MC, Jorenby DE, Baker TB. Gender differences in smoking cessation. J Consult Clin Psychol 1999; 67:555-62.

12. Osler M, Prescott E, Godtfredsen N, Hein HO, Schnohr P. Gender and determinants of smoking cessation: a longitudinal study. Prev Med 1999; 29:57-62.

13. Tauras JA, Chaloupka FJ. Determinants of smoking cessation: an analysis of young adult men and women. Cambridge: National Bureau of Economic Research; 1999 (NBER Working Paper Series, 7262).

14. Douglas S. The duration of the smoking habit. Economic Inquiry 1998; 36:49-64.

15. Paperwalla KN, Levin TT, Weiner J, Saravay SM. Smoking and depression. Med Clin North Am 2004; 88:1483-94, x-xi.

16. McClave AK, Dube SR, Strine TW, Kroenke K, Caraballo RS, Mokdad AH. Associations between smoking cessation and anxiety and depression among U.S. adults. Addict Behav 2009; 34:491-7.

17. World Health Organization. GATS (Global Adult Tobacco Survey). http://www.who.int/tobacco/ surveillance/gats/en/index.html (accessed on 08/ May/2012).

18. Instituto Brasileiro de Geografia e Estatística. Tabagismo. Rio de Janeiro: Instituto Brasileiro de Geografia e Estatística; 2008.

19. World Health Organization. Guidelines for controlling and monitoring the tobacco epidemic. Geneva: World Health Organization; 1998.

20. Raherison C, Marjary A, Valpromy B, Prevot S, Fossoux H, Taytard A. Evaluation of smoking cessation success in adults. Respir Med 2005; 99:1303-10.

21. Khuder SA, Dayal HH, Mutgi AB. Age at smoking onset and its effect on smoking cessation. Addict Behav 1999; 24:673-7.

22. Broms U, Silventoinen K, Lahelma E, Koskenvuo M, Kaprio J. Smoking cessation by socioeconomic status and marital status: the contribution of smoking behavior and family background. Nicotine Tob Res 2004; 6:447-55.

23. Barros MBA, Francisco PMSB, Lima MG, César CLG. Social inequalities in health among the elderly. Cad Saúde Pública 2011; 27 Suppl 2:S198-208.

24. Silva GA, Valente JG, Almeida LM, Moura EC, Malta DC. Tabagismo e escolaridade no Brasil, 2006. Rev Saúde Pública 2009; 43:48-56.

25. Hymowitz N, Cummings KM, Hyland A, Lynn WR, Pechacek TF, Hartwell TD. Predictors of smoking cessation in a cohort of adult smokers followed for five years. Tob Control 1997; 6 Suppl 2:S57-62.

26. Hyland A, Li Q, Bauer JE, Giovino GA, Steger C, Cummings KM. Predictors of cessation in a cohor of current and former smokers followed over 13 years. Nicotine Tob Res 2004; 6 Suppl 3:S363-9.

27. Luppi CHB, Alves MVMFF, Santos AA. Programa de cessação ao tabagismo: perfil e resultados. Revista Ciência em Extensão 2006; 2(2). http://ojs.unesp. br/index.php/revista_proex/article/view/196. (accessed on 21/Nov/2012).
28. Silva GA, Valente JG, Malta DC. Tendências do ta bagismo na população adulta das capitais Brasileiras: uma análise dos dados de inquéritos telefônicos de 2006 a 2009. Rev Bras Epidemiol 2011; 14:103-14.

29. Secretaria de Gestão Estratégica e Participativa, Secretaria de Vigilância em Saúde, Ministério da Saúde. Vigitel Brasil 2006: vigilância de fatores de risco e proteção para doenças crônicas por inquérito telefônico. Brasília: Ministério da Saúde; 2007. (Série G. Estatística e Informação em Saúde).

30. McKee SA, Maciejewski PK, Falba T, Mazure CM. Sex differences in the effects of stressful life events on changes in smoking status. Addiction 2003; 98:847-55.

31. Critchley JA, Capewell S. Mortality risk reduction associated with smoking cessation in patients with coronary heart disease: a systematic review. JAMA 2003; 290:86-97.

32. Videtic GM, Stitt LW, Dar AR, Kocha WI, Tomiak AT, Truong PT, et al. Continued cigarette smoking by patients receiving concurrent chemoradiotherapy for limited-stage small-cell lung cancer is associ ated with decreased survival. J Clin Oncol 2003; 21:1544-9.

33. Tammemagi CM, Neslund-Dudas C, Simoff M, Kvale P. Smoking and lung cancer survival: the role of comorbidity and treatment. Chest 2004; 125 : 27-37.

34. Gritz ER, Vidrine DJ, Cororve Fingeret M. Smoking cessation: a critical component of medical management in chronic disease populations. Am J Prev Med 2007; 33(6 Suppl):S414-22.

35. Presman S, Carneiro E, Gigliotti A. Tratamentos não-farmacológicos para o tabagismo. Rev Psiquiatr Clín (São Paulo) 2005; 32:267-75.

36. Lima-Costa MF. Estilos de vida e uso de serviços preventivos de saúde entre adultos filiados ou não a plano privado de saúde (inquérito de saúde de Belo Horizonte). Ciênc Saúde Coletiva 2004; 9:857-64.

37. Marcus BH, Albrecht AE, King TK, Parisi AF, Pinto BM, Roberts M, et al. The efficacy of exercise as an aid for smoking cessation in women: a randomized controlled trial. Arch Intern Med 1999; 159: 1229-34.

38. Horn K, Dino G, Branstetter SA, Zhang J, Noerachmanto N, Jarrett T, et al. Effects of physical activity on teen smoking cessation. Pediatrics 2011 128:e801-e811.

39. Ussher MH, Taylor A, Faulkner G. Exercise interventions for smoking cessation. Cochrane Database Syst Rev 2008; (4):CD002295.

40. Trigo M, Rocha E. Cessação de hábitos tabágicos em doentes coronários. Acta Méd Port 2002; 15:337-44.

41. Tanni SE, Iritsu NI, Tani M, Camargo PAB, Sampaio MGE, Godoy I, et al. Avaliação do conhecimento sobre tabagismo em pacientes internados. J Bras Pneumol 2010; 36:218-23.

Submitted on 17/Aug/2012

Final version resubmitted on 15/Jan/2013

Approved on 01/Feb/2013 